\title{
RESEARCH PAPER \\ Responses of young Punica granatum plants under four different water regimes
}

\author{
Felipe Bugueño, Nieggiorba Livellara, Fernando Varas, Pedro Undurraga, \\ Mónica Castro, and Eduardo Salgado \\ Pontificia Universidad Católica de Valparaíso. Escuela de Agronomía. Casilla 4 - D, Quillota, Chile.
}

\begin{abstract}
F. Bugueño, N. Livellara, F. Varas, P. Undurraga, M. Castro, and E. Salgado. 2016. Responses of young Punica granatum plants under four different water regimes. Cien. Inv. Agr. 43(1):49-56. We studied the effect of four irrigation treatments, expressed as fractions $(1.3,1.0,0.7$ and 0.3$)$ of crop evapotranspiration (ETc), on the growth of young pomegranate plants in central Chile $\left(32^{\circ} 32^{\prime} \mathrm{S}\right.$ and $\left.71^{\circ} 06^{\prime} \mathrm{W}\right)$. We evaluated the effect of the four treatments on canopy volume (CV) during two growing seasons. For 28 days during the second growing season, we evaluated soil moisture content $(\theta)$, the soil-moisture depletion factor $(p)$, trunk cumulative growth (TCG), trunk growth rate (TGR) and maximum daily trunk shrinkage (MDS). We found relationships between CV and TCG and between CV and TGR. There were no differences in MDS among the irrigation treatments. We observed significant water stress in plants in the $0.3 \mathrm{ETc}$ treatment $(p=0.47)$. The highest growth was observed in plants in the 1.3 ETc treatment, which suggests that the crop coefficient $(\mathrm{Kc})$ was underestimated.
\end{abstract}

Key words: Dendrometer, depletion fraction $(p)$, canopy volume $(\mathrm{CV})$, maximum daily trunk shrinkage (MDS), trunk diameter, trunk growth rate (TGR), water stress.

\section{Introduction}

The pomegranate tree (Punica granatum L.) is a species that is a species that can adapt to a wide range of climates and water conditions (Rodríguez et al., 2012). Pomegranates originated in the Middle East, an area characterized by high temperatures for most of the year, and short periods of rainfall (Melgarejo, 2001). However, the secondary distribution zone of pomegranate is the Mediterranean, where periods of rainfall are

Received July 30, 2015. Accepted January 13, 2016. Corresponding author: esalgado@ucv.cl longer and the climate is more temperate (Levin, 1994). Pomegranate trees are a rustic crop, with low water and nutrient demands. A thick trunk (a characteristic of the Lythraceae family) allows this tree to maintain water during long periods of shortage (Rodríguez et al., 2012). However, water restrictions limit the growth of new buds, shoots and trunks, in young and adult plants (Moriana and Fereres, 2002; Martín-Vertedor et al., 2011).

Due to the organoleptic character of the pomegranate fruit and its benefits to human health, pomegranate consumption has increased notably in recent decades (Melgarejo, 2001; Rodríguez et 
al., 2012). Currently, 300,000 hectares globally are planted with pomegranate trees. Production doubled from 1990 to 2010, particularly in semiarid regions such as Spain (Melgarejo, 2001). This increase in production may be related to the components of the fruit, which are used to control pathogens and to treat diseases such as cancer and hypertension (Tehranifar et al., 2011).

The increase in the planted surface area, limited water availability and the marginality of cropping areas allowed by the rustic nature of the species, have led to the need for increased water use efficiency through irrigation management. Under deficient irrigation, pomegranate plants develop mechanisms to avoid and tolerate stress (Rodríguez et al., 2012). The development and quality of fruits are also affected by deficient irrigation, although in some cases, fruit quality has been improved (Lawand et al., 1991; Mellisho et al., 2012). Overall, restricting irrigation produces a decrease in photosynthesis and stomatal conductance, affecting the plants' vegetative growth (Intrigliolo et al., 2011b). In addition, there is an inverse relationship between salt content and evapotranspiration in young pomegranate trees. (Bhantana and Lazarovitch, 2010). Daily trunk diameter fluctuations (TDF) have also been studied and show that maximum daily trunk shrinkage (MDS) is more sensitive than other TDF and other types of non-dendrometric observations (Intigriolo et al., 2011a; Galindo et al., 2013). However, most of these studies assessed plants in the production phase, except the study by Bhantana and Lazarovitch (2010). Other studies showed that dendrometric responses varied with species and plant age (Ortuño et al., 2010). Therefore, it is yet to be determined precisely when young pomegranate plants can support water restrictions, without experiencing a significant reduction in growth.

In the present study, we analyzed the interaction between variables related to trunk diameter fluctuations (TDF) and the vegetative responses of young pomegranate plants subjected to different water regimes. The objective of the study was to determine the effect of four water regimes on TDF and their possible correlation with Punica granatum L. plant growth.

\section{Materials and methods}

\section{Plant materials and experimental conditions}

The experiments were conducted during the 2010-11 and 2011-12 growing seasons, and corresponded to the first two years of plant growth. Pomegranates were planted in the province of Petorca, in the region of Valparaiso, in central Chile (32 $32^{\prime}$ S and $71^{\circ} 06^{\prime}$ W). Santibáñez et al. (1990) characterized the area as having a mesothermal stenothermic semiarid Mediterranean steppe climate with low atmospheric humidity, and sparse and irregular rainfall with mean annual precipitation of $220 \mathrm{~mm}$. The mean annual precipitation recorded during the study was 105 $\mathrm{mm}$. Rainfall was concentrated in the months of May-September. The mean annual reference evapotranspiration was $1296 \mathrm{~mm}$. The main soil type was Mollisol, which contained a dark wellstructured surface layer with high base saturation and sandy loam texture up to a depth of $68 \mathrm{~cm}$. The field capacity (FC) was $0.24 \mathrm{~m}^{3} \mathrm{~m}^{-3}$ and the available water capacity (AWC) was $0.12 \mathrm{~m}^{3} \mathrm{~m}^{-3}$.

Pomegranate plants (Wonderful) were planted in a $5 \times 5 \mathrm{~m}$ area in October of 2010 . The plants were obtained from cuttings and were planted in the field after one year in a nursery. At the time of planting, all plants presented homogenous development in terms of height and canopy growth. A total of four rows were planted with 8 plants per row, of which 12 plants were chosen at random, excluding those plants on the boundaries. The treatments consisted of the application of $130 \%$ $\left(\mathrm{T}_{130}\right), 100 \%\left(\mathrm{~T}_{100}\right), 70 \%\left(\mathrm{~T}_{70}\right)$ and $30 \%\left(\mathrm{~T}_{30}\right)$ of the water lost as crop evapotranspiration (ETc). Reference evapotranspiration ( $\mathrm{ET}_{0}$ ) was calculated in accordance with Penman-Monteith (Allen et al., 1998), and the values for the crop coefficient $\left(\mathrm{K}_{\mathrm{c}}=0.6\right)$ of young plants were taken from mea- 
surements by Bhantana and Lazarovitch (2010). The total flow rate per plant was adjusted using different numbers of drippers and/or different dripper flow rates (Table 1).

Table 1. Number of drippers and water volume applied in each treatment.

\begin{tabular}{|c|c|c|c|c|c|}
\hline \multirow[b]{3}{*}{ Treatment } & \multicolumn{4}{|c|}{ Flow rate per dripper, $\mathrm{L} \mathrm{h}^{-1}$} & \multirow{3}{*}{$\begin{array}{l}\text { Flow rate per } \\
\text { plant, } \mathrm{L} \mathrm{h}^{-1}\end{array}$} \\
\hline & 2 & 3 & 4 & 8 & \\
\hline & \multicolumn{4}{|c|}{ Number of drippers per plant } & \\
\hline $\mathrm{T}_{130}$ & 1 & 1 & & 1 & 13 \\
\hline $\mathrm{T}_{100}$ & 1 & & & 1 & 10 \\
\hline $\mathrm{T}_{70}$ & & 1 & 1 & & 7 \\
\hline $\mathrm{T}_{30}$ & & 1 & & & 3 \\
\hline
\end{tabular}

\section{Measurements}

The following variables were measured to evaluate treatment effects: canopy volume (CV), trunk cumulative growth (TCG), maximum daily trunk shrinkage (MDS) and trunk growth rate (TGR). The data for calculating CV were collected at the end of the 2010-11 and 2011-12 growing seasons, and CV corresponded to canopy height and diameter (Equation 1). Additional data, TCG, MDS and TGR, were collected from day of year (DOY) 32 to DOY 60 at the end of the 2011-2012 growing season (Livellara et al., 2011; Bhantana and Lazarovitch, 2010).

$$
C V=\left(\frac{d_{1}+d_{2}+d_{3}}{3}\right) \times h
$$

where:

$\begin{array}{ll}\mathrm{CV}: & \text { Canopy volume }\left(\mathrm{m}^{3}\right) \\ \mathrm{h}: & \text { Canopy height }(\mathrm{m}) \\ d_{1}: & \text { Canopy diameter at } \mathrm{h} / 4(\mathrm{~m}) \\ d_{2}: & \text { Canopy diameter at } \mathrm{h} / 2(\mathrm{~m}) \\ d_{3}: & \text { Canopy diameter at } 3 \mathrm{~h} / 4(\mathrm{~m})\end{array}$

The trunk cumulative growth (TCG), trunk growth rate (TGR) and maximum daily shrinkage (MDS) were estimated using linear variable differential transducers (LVDT) (Intrigliolo et al., 2011a; Fernández and Cuevas, 2010), model DD$\mathrm{S}$, Ecomatik, with a precision of $\pm 2 \mu \mathrm{m}$. Sensors were placed on the trunks of 12 plants at $20 \mathrm{~cm}$ above the ground (Fernández and Cuevas (2010). Measurements were made every 30 minutes, in accordance with Intrigliolo et al. (2011a). The calculations of MDS and TGR were performed according to Equations 2 and 3 (Goldhamer and Fereres, 2001), and TCG was calculated according to Equation 4.

$\begin{array}{ll}T G R=M X T D_{(t+1)}-M X T D_{(t)} & \text { Eq. } 2 \\ M D S=M X T D_{(t)}-M N T D_{(t)} & \text { Eq. } 3 \\ T C G=\sum_{D O Y=32}^{D O Y=58} T G R & \text { Eq. } 4\end{array}$

where:

TGR: $\quad$ Trunk growth rate $\left(\mu \mathrm{m} \mathrm{d}^{-1}\right)$

MDS: $\quad$ Maximum daily trunk shrinkage $(\mu \mathrm{m})$

MXTD $_{(\mathrm{t})}$ : Maximum daily trunk diameter for day $\mathrm{t}(\mu \mathrm{m})$

$\operatorname{MXTD}_{(t+1)}$ : Maximum daily trunk diameter for day $\mathrm{t}+1(\mu \mathrm{m})$

MNTD $_{(t)}: \quad$ Minimum daily trunk diameter for day $\mathrm{t}(\mu \mathrm{m})$

TCG: $\quad$ Trunk cumulative growth $(\mu \mathrm{m})$

DOY: Day of year

The meteorological data (temperature, relative humidity, solar radiation and wind speed) were collected using an automatic weather station (Davis Instrument, Vantage Pro 2, USA) located 40 meters from the plants. The soil volumetric moisture content $(\Theta, \mathrm{v} / \mathrm{v})$ was monitored using an FDR capacitance probe (ECHO EC-5, Decagon Devices, Inc., USA). The device was calibrated specifically for this type of soil (Starr and Paltineanu, 2002). Sensors were placed $10 \mathrm{~cm}$ from each trunk along the crop line, at a depth of $20 \mathrm{~cm}$ (rooting depth was $0.5 \mathrm{~m}$ ). The depletion fraction $(p)$ was determined for each treatment according to Equation 5. Data loggers recorded the climate and soil conditions every 30 minutes.

\section{Experimental design and statistical analysis}

A completely randomized design was used, comprising four treatments with three replicates 
(one plant per replicate), surrounded by boundary plants. The data were analyzed using analysis of variance (ANOVA) in MINITAB 16.0 (Minitab Inc., Minitab ${ }^{\circledR}$ statistical software), and the means were separated using Tukey tests $(\mathrm{P} \leq 0.05)$.

$p=\frac{\left(\theta_{F C}-\theta_{\text {min }}\right)}{\left(\theta_{F C}-\theta_{W P}\right)}$

where:

$\begin{array}{ll}p: & \text { Depletion fraction } \\ \theta_{\mathrm{FC}}: & \text { Water content at field capacity }\left(\mathrm{m}^{3} \mathrm{~m}^{-3}\right) \\ \theta_{\mathrm{WP}}: & \text { Water content at wilting point }\left(\mathrm{m}^{3} \mathrm{~m}^{-3}\right) \\ \theta_{\text {min }}: & \text { Minimum mean water content observed } \\ & \text { in each treatment }\left(\mathrm{m}^{3} \mathrm{~m}^{-3}\right)\end{array}$

\section{Results and discussion}

Soil moisture content $(v / v)$ and reference evapotranspiration

Soil moisture content. The data showed that the soil moisture content concurred with the irrigation treatments that were applied (Figure 1A). The soil moisture content under $\mathrm{T}_{130}$ remained over field capacity (FC), but the soil moisture contents under $\mathrm{T}_{100}$ and $\mathrm{T}_{70}$ were under field capacity, with the exception of the hours immediately following irrigation. The soil moisture content under $\mathrm{T}_{30}$ was always under field capacity and was the lowest among the irrigation treatments. The soil-moisture depletion factor $(p)$ for pomegranate was not known prior to this study; however, the water stress experienced by plants in the irrigation treatments allows us to suggest such a threshold value.

For table grapes and kiwi trees, $(p)$ is 0.35 ; for almond and pistachio trees, $(p)$ is 0.40 ; for grapevine, $(p)$ is 0.45 ; for apple, cherry, pear, peach, citrus and walnut trees, $(p)$ is 0.50 ; for olive, $(p)$ is 0.65; and for avocado, $(p)$ is 0.70 (Allen et al., 1998). Our data suggest that, for young pomegranates, the depletion factor $(p)$ should lie between 0.12 and 0.47 . For $\mathrm{T}_{130}$ and $\mathrm{T}_{100}, \mathrm{p}$-values were less than the range of the majority of the species listed above, but for $\mathrm{T}_{70}$ and $\mathrm{T}_{30}$, the values were within the range that we suggested. Because plant water use is associated with soil moisture availability, the $\mathrm{p}$ factor represents the threshold soil water deficit (Lamm et al., 1994).

The reference evapotranspiration remained constant during the 28 days of the analysis period, with a mean value of $5.0 \mathrm{~mm} \mathrm{~d}^{-1} \pm 0.47 \mathrm{~mm}$. On two days, reference evapotranspiration was clearly low: $3.5 \mathrm{~mm} \mathrm{~d}^{-1}$ and $4.2 \mathrm{~mm} \mathrm{~d}^{-1}$ (DOY 54 and 55, respectively). A decreasing trend in reference evapotranspiration values also occurred over time. This decrease was related to the end of the summer season and the subsequent decrease in solar radiation and temperature (Figure 1B).

\section{Effects of irrigation on vegetative growth}

Canopy growth. Water restrictions reduced the vegetative growth of young pomegranate plants at the end of the second growing season (Figure 2). During the first season, all irrigation treatments supplied enough water for plants, due to their small size and low water requirements. However, during the second growing season, pomegranate trees had a lower capacity for tolerating water restrictions (Melgarejo, 2001; Bhantana and Lazarovitch et al., 2010). Similar results were found for olive and cherry trees (Martín-Vertedor et al., 2011; Livellara et al., 2011), but there were no effects of irrigation regimes on canopy volume in peach trees (Pérez-Pastor et al., 2014). This study showed that canopy growth was at a maximum when soil watering was equivalent to $100 \%$ or $130 \%$ of evapotranspiration (ETc). If soil watering was equivalent to $70 \%$ of ETc, plant responses were unclear; there was no reduction in the canopy growth under the treatment of $70 \%$ of ETc, but the low soil moisture at this level of irrigation might have led to the start of plant water stress. Plants subjected to water deficits have been known to modify their patterns of water absorption, transpiration, enzyme activity and photosynthesis, 


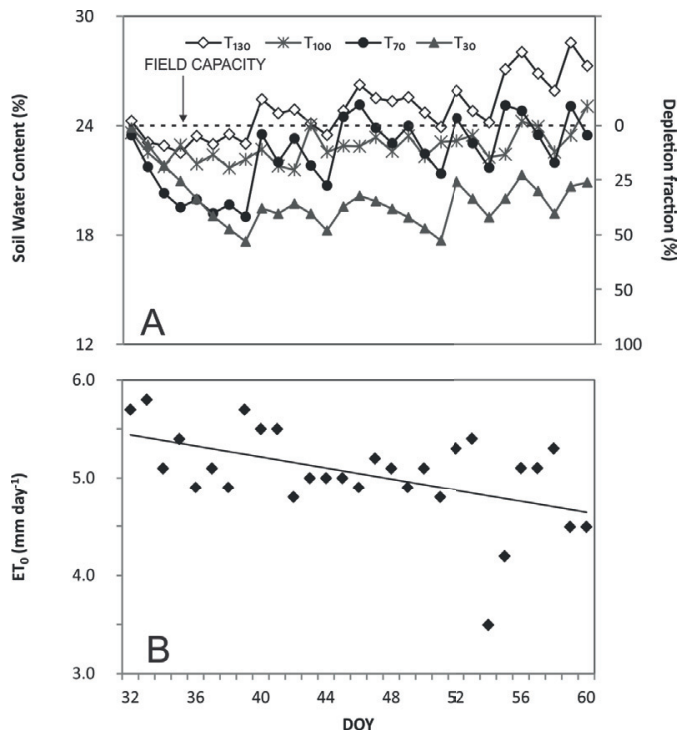

Figure 1. A) Soil water content (SWC) and depletion fraction (p) for each treatment. The discontinuous line (---) represents the field capacity. B) Reference evapotranspiration during the study period. The continuous line $(-)$ represents the trend line of the $\mathrm{ET}_{0}$ values.

interfering directly with the development of new shoots and canopy expression (Nortes et al., 2005). A deficient water regime during the first stages of growth could completely inhibit vegetative development, depending on the age of the plant (Martín-Vertedor et al., 2011). This effect is attributed to a reduction in stomatal conductance, transpiration and photosynthesis, and the subsequent decreased growth of young plants (Intrigliolo et al., 2011a). Canopy growth is fundamental during the first years of development, as it greatly influences the amount of foliage available, the photosynthetic capacity and the final size of the plant (Intrigliolo and Castel, 2005).

Trunk cumulative growth (TCG). For the period between DOY 32 and DOY 58, TCG was affected by the irrigation treatments (Figure 3), similarly to the effects of irrigation treatments on CV (Figure 2). Previous studies showed that water restrictions reduced cumulative trunk growth in other species (Nortes et al., 2005), and our results suggest that trunk cumulative growth was also sensitive to water restrictions in pomegranate trees. The maximum TCG occurred when plants were ir-

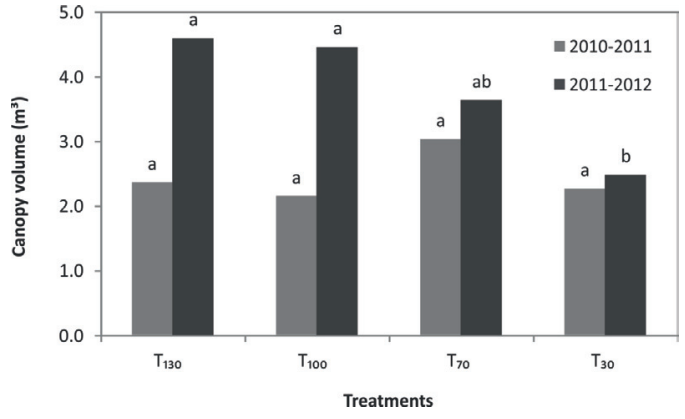

Figure 2. Canopy volume at the end of the 2010-2011 and 2011-2012 growing seasons. For a growing season, treatments with the same letters were not significantly different (Tukey test; $\mathrm{P} \leq 0.05$ ).

rigated at $130 \%$ of ETc, and plants experienced significant water stress when irrigated at $30 \%$ of ETc. Plants did not show a clear response when irrigation ranged between $100 \%$ and $70 \%$ of ETc. These results were similar to those obtained by Martín-Vertedor et al. (2011), in which adult olive plants that were irrigated to meet $100 \%$ of their transpiration demand showed more growth, but a slight water restriction did not affect growth. It has been shown that the growth magnitude of each plant is strongly related to the amount of water applied and its subsequent water status (Mellisho et al., 2012). It has also been shown that the magnitude of the trunk growth response is species specific (Fernández and Cuevas, 2010).

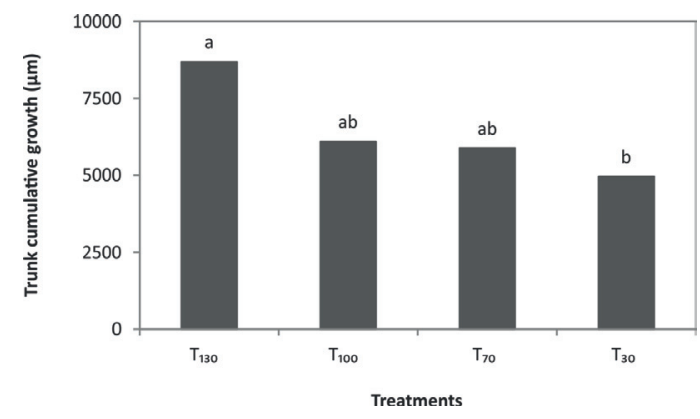

Figure 3. Trunk cumulative growth (TCG) for each treatment during the study period. Treatments with the same letters were not significantly different (Tukey test; $\mathrm{P} \leq 0.05$ ).

Maximum daily trunk shrinkage (MDS) and trunk growth rate (TGR). The irrigation treatments affected TGR, although no differences were observed 
for MDS (Figure 4). These results differed from the results for adult plants, where MDS was the most sensitive variable and the most useful for irrigation programming (Intrigliolo et al., 2011a; Galindo et al., 2013). However, in other studies conducted using young almond, lemon, olive and cherry trees, TGR was also sensitive to water availability (Moriana and Fereres, 2002; Nortes et al., 2005; Livellara et al., 2011). The higher sensitivity observed for TGR was associated with the fact that young plants characteristically have high growth rates, specific to their age, thus limiting the usefulness of MDS as a response variable (Moriana and Fereres, 2002). Other factors such as the combined effects of water availability, evapotranspiration and plant age (Goldhamer and Fereres, 2001) may also influence MDS, making this variable less useful for young plants (Nortes et al., 2005). Therefore, our results indicate that TGR was sensitive to water restrictions in young pomegranate plants. The response of TGR was similar to the response of $\mathrm{CV}$ and TCG. The response of TGR was more
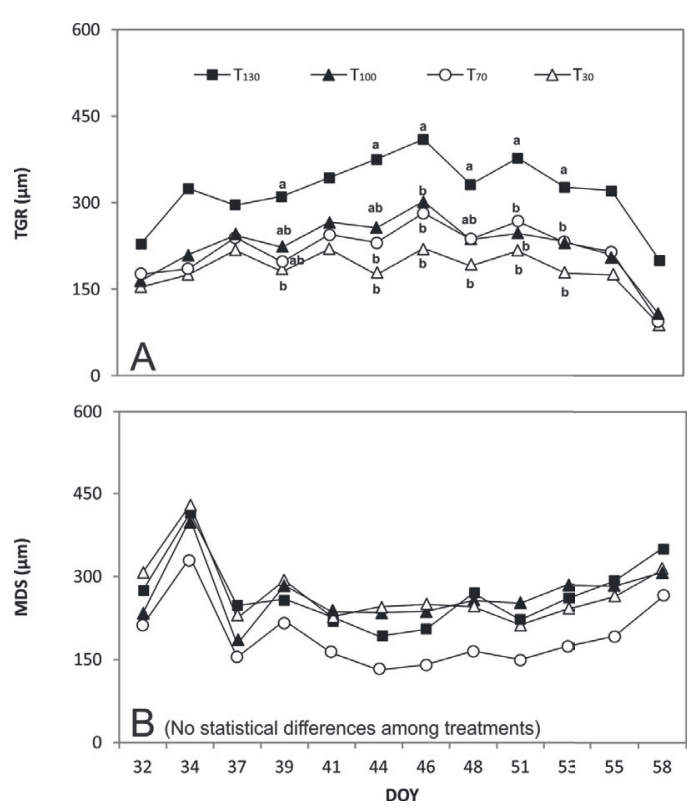

Figure 4. A) Trunk growth rate (TGR) and B) maximum daily trunk shrinkage (MDS) for each irrigation treatment. Treatments with the same letters were not significantly different (Tukey test; $\mathrm{P} \leq 0.05$ ). sensitive, with a difference occurring when irrigation was at for $130 \%$ of ETc compared to 100 , 70 and $30 \%$ of ETc, for DOY 46, 51 and 53 . The difference between irrigation at 130 and $100 \%$ of ETc suggest that the values of Kc applied in this study were underestimated. In addition, our results suggest that TGR values over $300 \mu \mathrm{m} \mathrm{d}^{-1}$ would be optimum for the trunk growth of young pomegranate plants, but values under $200 \mu \mathrm{m} \mathrm{d}^{-1}$ would cause some damage.

In this study, an integrated analysis of variables corresponding to aerial and trunk growth allowed us to conclude the following: (1) there was agreement in the overall behavior of CV, TCG and TGR; (2) TGR was the most sensitive of these variables to water stress; (3) the highest canopy growth occurred when the irrigation treatment was equivalent to $130 \%$ of ETc; (4) plant water stress was significant when the irrigation treatment was equivalent to $30 \%$ of ETc, and (5) the soil moisture depletion factor $(p)$ for pomegranate should be lower than 0.47 .

\section{Acknowledgements}

Petorca Province Water Management Project. Proyecto BIP. 30082951-0. SEREMI Agricultura de Valparaíso and Pontificia Universidad Católica de Valparaíso, Chile. 


\title{
Resumen
}

\begin{abstract}
F. Bugueño, N. Livellara, F. Varas, P. Undurraga, M. Castro y E. Salgado. 2016. Respuesta de plantas jóvenes de Punica granatum, sometidas a cuatro regímenes hídricos. Cien. Inv. Agr. 43(1): 49-56. Se estudió el efecto de cuatro tratamientos de riego como fracciones (1.3, 1.0, 0.7 y 0.3 ) de la evapotranspiración de cultivo (ETc) sobre variables de crecimiento de plantas jóvenes de granado en Chile central (provincia de Petorca) (32 $32^{\prime}$ S and $71^{\circ} 06^{\prime} \mathrm{W}$ ). Se evaluó el volumen de copa $(\mathrm{CV})$ durante las dos primeras temporadas de crecimiento de las plantas. En la segunda temporada de crecimiento se determinó durante 28 días el contenido de humedad del suelo $(\Theta)$, la fracción de agotamiento de la humedad del suelo $(p)$, el crecimiento acumulado del tronco (TCG), la tasa de crecimiento del tronco (TGR) y contracción máxima del tronco (MDS). Existió relación entre el CV y las variables de crecimiento del tronco (TCG y TGR). La MDS no presentó diferencias entre los tratamientos. Se evidenció un estrés significativo cuando se rego un $30 \%$ de la evapotranspiración de cultivo (ETc), bajo estas condiciones las plantas fueron sometidas valores de $(p)$ de 0.47 . El mayor crecimiento fue observado con 1.3ETc por lo que se considera que se subestimo el valor de coeficiente de cultivo $(\mathrm{kc})$ en el presente estudio.
\end{abstract}

Palabras clave: Dendrómetro, contracción máxima diaria del tronco (MDS), diámetro del tronco, estrés hídrico, fracción de agotamiento $(p)$, tasa de crecimiento del tronco (TGR), volumen de copa $(\mathrm{CV})$.

\section{References}

Allen, R. G., Pereira, L. S., Raes, D., and M. Smith. 1998. Crop evapotranspiration-Guidelines for computing crop water requirements. FAO Irrigation and drainage, paper 56. FAO, Rome, Italy. 300(9): D05109.

Bhantana, P. and N. Lazarovitch. 2010. Evapotranspiration, crop coefficient and growth of two young pomegranate (Punica granatum L.) varieties under salt stress. Agricultural Water Management 97(5): 715-722.

Fernández, J.E. and M.V. Cuevas. 2010. Irrigation scheduling from stem diameter variations: a review. Agricultural and Forest Meteorology 150:135-151.

Galindo, A., P. Rodríguez, C.D. Mellisho, E. Torrecillas, A. Moriana, Z.N. Cruz, and A. Torrecillas. 2013. Assessment of discretely measured indicators and maximum daily trunk shrinkage for detecting water stress in pomegranate trees. Agricultural and Forest Meteorology 180: 58-65.

Goldhamer, D.A., and E. Fereres. 2001. Irrigation scheduling protocols using continuously record- ed trunk diameter measurements. Irrigation Science 20(3): 115-125.

Intrigliolo, D. S. and J.R. Castel. 2005. Effects of regulated deficit irrigation on growth and yield of young Japanese plum trees. Journal of Horticultural Science \& Biotechnology 80: 177-182.

Intrigliolo, D.S., H. Puerto, L. Bonet, J.J. Alarcón, E. Nicolas, and J. Bartual. 2011a. Usefulness of trunk diameter variations as continuous water stress indicators of pomegranate (Punica granatum) trees. Agricultural Water Management 98: 1462-1468.

Intrigliolo, D.S., E. Nicolas, L. Bonet, P. Ferrer, J.J. Alarcón, and J. Bartual, J. 2011b. Water relations of field grown Pomegranate trees (Punica granatum) under different drip irrigation regimes. Agricultural Water Management 98:691-696.

La Malfa, S., A. Gentile, F. Domina, and E. Tribulato. 2006. Primosole: A new selection from Sicilian pomegranate germplasm. In: I International Symposium on Pomegranate and Minor Mediterranean Fruits 818:125-132.

Lamm, F.R., D.H. Rogers, and H.L. Manges. 1994. Irrigation scheduling with planned soil water 
depletion. Transactions of the ASAE 37:14911498.

Lawand, B.T., V.K. Patil, and P.V. Patil. 1991. Effect of different water regimes on fruit quality of pomegranate (Punica granatum L.). Frontier in Tropical Fruit Research 321:677-683.

Livellara, N., F. Saavedra, and E. Salgado. 2011. Plant based indicators for irrigation scheduling in young cherry trees. Agricultural Water Management 98: 684-690.

Levin, G. 1994. Pomegranate (Punica granatum L.) plant genetic resources in Turkmenistan. Plant Genetic Resources Newsletter 97:31-36.

Martín-Vertedor, A.I., J.M.P. Rodríguez, H.P. Losada, and E.F. Castiel. 2011. Interactive responses to water deficits and crop load in olive (Olea europaea L., cv. Morisca) I.-Growth and water relations. Agricultural Water Management 98:941949.

Mellisho, C., I. Egea, A.Galindo, P. Rodríguez, J. Rodríguez, W. Conejero, F. Romojaro, and A. Torrecillas. 2012. Pomegranate (Punica granatum L.) fruit response to different deficit irrigation condition. Agricultural Water Management 114:30-36.

Melgarejo, P. 2001. El cultivo del granado.Ed. Antonio Madrid Vicente, Madrid, España. 230 pp.

Moriana, A., and E. Fereres. 2002. Plant indicators for scheduling irrigation of young olive trees. Irrigation Science 21: 83-90.

Nortes, P.A., A. Pérez-Pastor, G. Egea, W. Conejero, and R. Domingo. 2005. Comparison of changes in stem diameter and water potential values for detecting water stress in young almond trees. Agricultural Water Management 77:296-307.

Ortuño, M.F., W. Conejero, F. Moreno, A. Moriana, D.S. Intrigliolo, C. Biel, C. Mellisho, A. PérezPastor, R. Domingo, M. Ruiz-Sánchez, J. Casa- desus, J. Bonany, and A. Torrecillas. 2010. Could trunk diameter sensors be used in woddy crops for irrigation scheduling? A review of current knowledge and future perspectives. Agricultural Water Management 97:1-11.

Pérez-Pastor, A., M.C. Ruiz-Sánchez, and R. Domingo. 2014. Effects of timing and intensity of deficit irrigation on vegetative and fruit growth of apricot trees. Agricultural Water Management 134: 110-118.

Rodríguez, P., C.D. Mellisho, W. Conejero, Z.N. Cruz, M.F. Ortuno, A. Galindo, and A. Torrecillas. 2012. Plant water relations of leaves of pomegranate trees under different irrigation conditions. Environmental and Experimental Botany 77: 19-24.

Santibáñez F., J.M. Uribe, and M. Vicencio. 1990. Atlas agroclimático de Chile: Regiones V y Metropolitana. $1^{\text {a }}$ Ed. Universidad de Chile, Santiago, Chile. 65 pp.

Starr, J.L., and I.C. Paltineanu. 2002. Methods for Measurement of Soil Water Content: Capacitance Devices. p. 463-474. In: J.H.Dane, and G.C.Topp (eds.). Methods of Soil Analysis: Part 4 Physical Methods. Soil Science Society of America, Inc.

Tardieu, F. and T. Simonneau. 1998. Variability among species of stomatal control under fluctuating soil water status and evaporative demand: modelling isohydric and anisohydric behaviours. Journal of experimental botany. 49(Special Issue): 419-432.

Tehranifar, A., Y. Selahvarzi, M. Kharrazi, and V.J. Bakhsh. 2011. High potential of agro-industrial by-products of pomegranate (Punica granatum L.) as the powerful antifungal and antioxidant substances. Industrial Crops and Products 34:1523-1527. 